\title{
Performance Analysis of Rural Banks and Sharia Rural Banks in Indonesia
}

\author{
Pandoyo $^{1}$, Mohammad Sofyan ${ }^{2}$ \\ \{p.pandoyo@gmail.com ${ }^{1}, \underline{\text { sofyan } @ \text {,stiami.ac.id }}^{2}$ \} \\ Institut Ilmu Sosial dan Manajemen Stiami, Jakarta, Indonesia ${ }^{1,2}$
}

\begin{abstract}
This study aims to analyze and compare the performance of rural banks with Islamic public finance banks. The data used during the 2011-2018 period is from Indonesian banking statistics and Islamic banking statistics published by the financial services authority. The results showed that rural banks with good capital capacity and keeping NPLs below $8 \%$ were able to generate profitability as expected by investors.
\end{abstract}

Keywords: Sharia rural banks, Rural banks, Performance Analysis

\section{Introduction}

Rural banks and sharia rural banks are institution finance aims to serve needs banking services for the economic community weakness and small businesses on Indonesia. BPR has a role important for small businesses in business improvement because micro and small businesses require capital easily and quickly. In the banking business, especially rural banks, management carries a huge risk of obtaining profitability as a reward for the risks covered. risks vary in different businesses but there is a positive relationship between risk and profit. Rural banks are increasingly pressed for the existence of commercial banks, foreign banks, and fintech peer to peer lending to put massive funding on microcredit (Sofyan, 2016). The existence of people's credit banks and Islamic people's financing banks is very important in helping the country's economic growth. The role of people's credit banks and Islamic people's financing banks in providing the funds needed to keep economic growth and development on track.

Rural banks utilize a combination of debt and equity in financing projects. A fixed percentage of interest is expected from the debt finance. The shari'a rural banks system which is based on the tenets of Sharia prescribes equity participation in investment. A distinctive feature of Islamic finance is that it does not allow the creation of debt through direct lending and borrowing of money or other financial assets. Debts can only be created through the sale or lease of real assets through lease based financing schemes (Babatunde \& Olaitan, 2013).

Rural banking follows conventional (interest-based) principles while sharia rural banking is based on interest-free principles and the principle of profit-and-loss sharing in performing their businesses as intermediaries. The rationale behind the prohibition of interest and the importance of profit-and-loss sharing in sharia rural banking has been discussed in many Islamic economics studies. Moreover, the Islamic profit-and-loss principle creates the relationship of financial trust and partnership between borrower, lender, and an intermediary (Yudistra, 2003). 
However, there are certain differences when analyzing the expected loss for conventional and sharia rural banks. Such differences appear in the way of breaking even the loss, caused by different types of products and services which these banks offer to their clients. In a conventional rural bank, the expected loss is broken even from the profit made by a bank in that period; the unexpected loss is to a certain extent broken even from the bank capital while the amount above that level is refunded from the insurance or the bank accepts bankruptcy (Kozarevic, Nuhanovic, \& Nurikic, 2013).

Sharia rural banks have a high growth rate and profitability over the rural banks. Moreover, the Sharia rural banks have high liquidity power over rural banks (Usman \& Khan, 2012). It has been realized that there exists a significant difference in credit performance between the two sets of banks. However, the study finds no major difference in profitability and liquidity performances between Sharia rural banks and rural banks (Samad, 2004).

In the banking system between rural banks and sharia rural banks, there are several differences in terms of company performance, namely: lies in returns and profit-sharing provided by customers to financial institutions and/or those given by financial institutions to customers (Rindawati, 2007). Rural bank's operational activities use interest as a means to earn income or charge interest on the use of funds and loans. While sharia rural banks use the principle of profit and loss sharing and do not provide interest.

Bank performance is a significant consideration for parties who have an interest in the bank. The parties with an interest in the bank include investors, creditors, customers, employees, the government, and the surrounding community. Given the number of interested parties so that the assessment of bank performance becomes very important. Bank performance is assessed based on how the company management is carried out all duties.

The bank's performance can be seen through regular financial reports issued by a go public bank. The information contained in the financial statements is information in the form of numbers which are records of transactions that occurred during one period. To find out the meaning of the numbers in the financial statements is necessary an analysis tool. The analytical tool used is usually financial statement analysis in the form of financial statement ratios.

Analysis of financial statements in the form of these ratios, among others, first, liquidity ratios, ratios This shows aspects of the company's ability to meet maturing obligations in the short term. The second ratio is leverage or solvency. Solvency measure the company's ability to meet obligations that are due in the long term. The third ratio is profitability, which is the company's ability to produce benefits with the resources they have (Darsono and Ashari, 2004).

\section{Method}


The purpose of this study is to evaluate the comparative financial performance of sharia and conventional BPR registered with the Indonesian Financial Services Authority. To obtain proven results, ROA, CAR, NPL/NPF, and LDR/FDR from the publication of Indonesian banking statistics and Islamic banking statistics during the period 2011 to 2018 are used. Data has been processed through Stata version 14.0 and Microsoft Excel and analysis has been conducted based on secondary data, descriptive statistics, and T-test.

\section{Result and Discussions}

The main advantages of the banking business based on conventional principles are obtained of the difference in interest on deposits given to depositors with interest on loans or credit extended. The profit from this difference in interest in the bank is known as the spread based. If a bank experiences a loss from the difference in interest, where is the interest rate savings are greater than the credit interest rate, this term is known as a negative spread.

For banks based on sharia principles, the term interest in providing services is not known to depositors and borrowers. In this bank, the bank services provided are adjusted with sharia principles by Islamic law. Islamic principles applied by banks sharia is financing based on the principle of profit-sharing (mudharabah), financing based on the principle of equity participation (musyarakah), the principle of buying and selling goods with obtaining profit (murabahah), or financing capital goods based on principles pure lease without choice (ijarah) or in the presence of a choice of transfer of ownership goods leased from the bank by another party (ijarah wa iqtina) (Kasmir, 2014). So like conventional banks, Islamic banks also offer a variety of products to customers although given on a different principle.

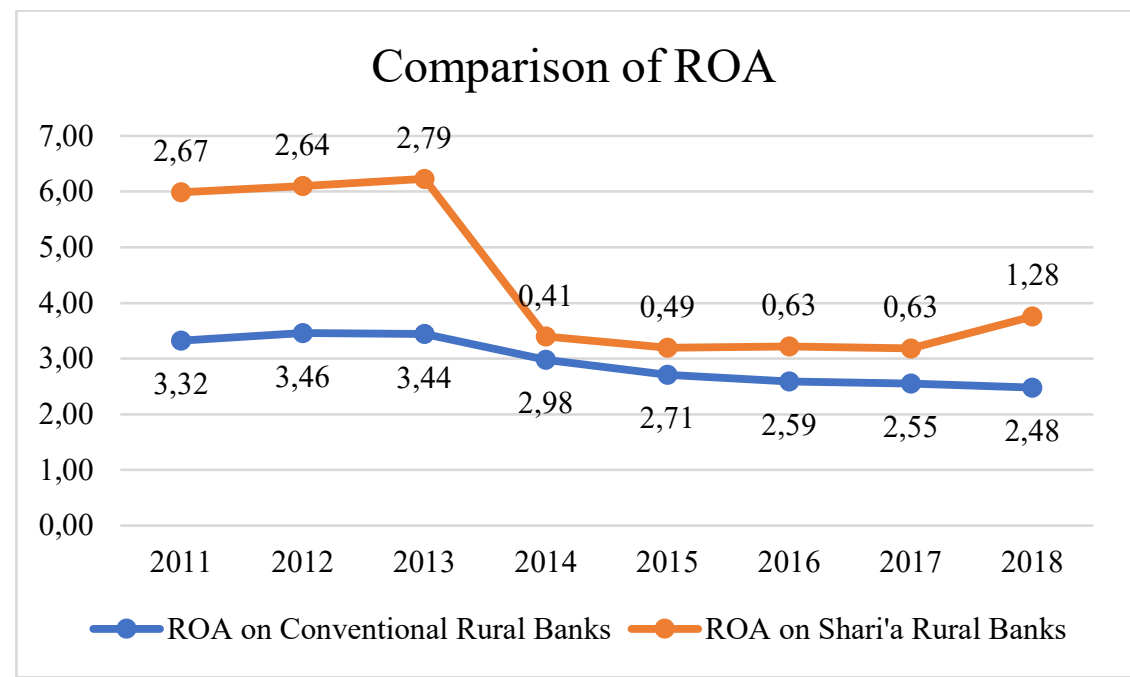

Figure 1. Comparison ROA of Sharia and Conventional Rural Banks

The overall trend of ROA is almost similar for Sharia BPR and conventional BPR. There is a downward trend in ROA from three segments from 2011 to 2018 in Figure 1. From 2011 to 2014 the ROA of sharia rural banks showed a decreasing trend, 2015 to 2018 showed an increasing trend. From 2012 to 2018 the ROA of conventional rural banks showed a 
decreasing trend. If we analyze the past 8 years, conventional rural banks have done far better than shari'a rural banks of the same size. ROA is used to measure a bank's ability to generate profits.

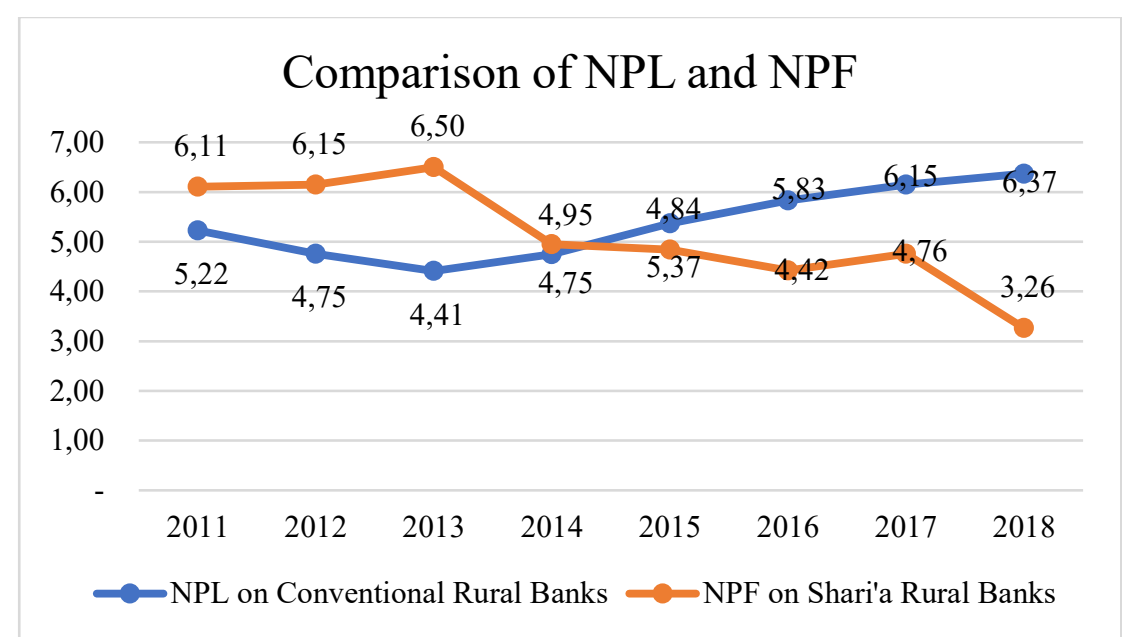

Figure 2. Comparison NPL/NPF of Sharia and Conventional Rural Banks

Figure 2. shows the risk of sharia rural bank's credit is better than conventional rural banks. From 2013 to 2018 sharia rural banks shows a good trend. whereas conventional rural banks show a bad trend. The high NPL/NPF causes a reduction in capital owned and reduced customer confidence.

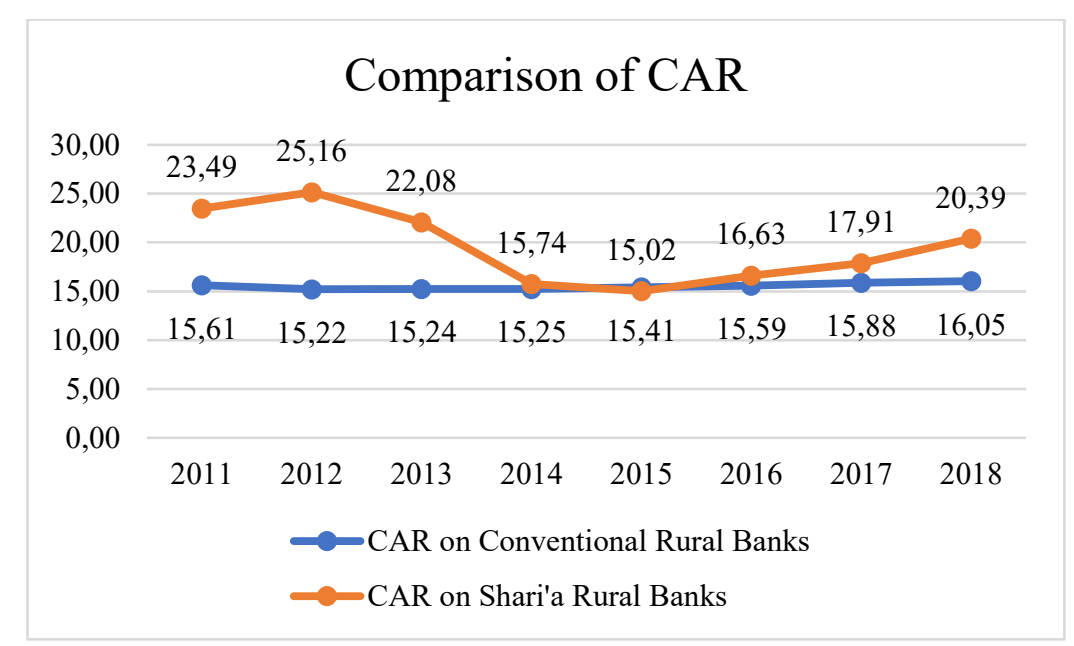

Figure 3. Comparison CAR of Sharia and Conventional Rural Banks

Figure 3. shows that sharia capital is better than conventional rural banks. With sufficient CAR, rural banks can operate well. 


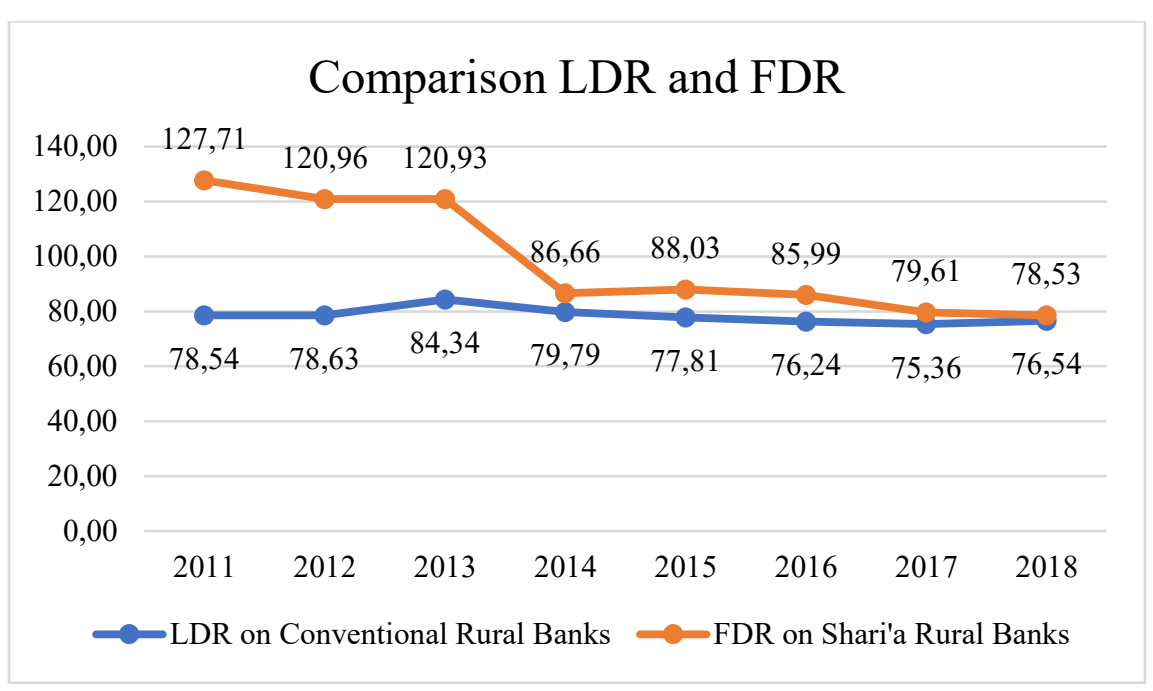

Figure 4. Comparison LDR/FDR of Sharia and Conventional Rural Banks

Figure 4. shows sharia rural bank's financing is better than conventional rural banks. The LDR is used to measure the ability to repay funds withdrawals with credit as a source of liquidity.

Table 1. Resume Two-sample t-test with equal variances

\begin{tabular}{lccc}
\hline & Conventional Rural Banks & Sharia Rural Banks & Different \\
\hline ROA & 2.94 & 1.44 & 1.5 \\
\hline CAR & 15.53 & 19.55 & -4.02 \\
\hline NPL / NPF & 5.36 & 5.12 & 0.24 \\
\hline LDR / FDR & 78.4 & 98.5 & -20.1 \\
\hline
\end{tabular}

Table 1. shows the differences in the ROA of conventional rural banks with sharia rural banks. Conventional rural banks are far better at 1.50 points than sharia rural banks. The differences in the CAR of sharia rural banks with conventional rural banks. sharia rural banks are far better at 4.02 point than rural banks. The differences in the NPF of sharia rural banks with NPL conventional rural banks. sharia rural banks are far better at 0,24 points than rural banks. The differences in the FDR of sharia rural banks with LDR conventional rural banks. sharia rural banks are far better 20.1 points than rural banks.

Rural bank's performance as indicated by high ROA as a basis for investor valuation. based on these results show that conventional rural banks are better than sharia rural banks. the results of this study are in line with the results of previous studies stating that conventional rural banks is far better than sharia rural banks (Babatunde \& Olaitan, 2013; Fayed, 2013; Massah \& Al-Sayed, 2015) 


\section{Conclusion}

This study compared rural bank's performance with sharia rural banks. based on the results of the study showed that the performance of rural banks was better than sharia rural banks. This study also shows that rural banks with good capital capabilities and keeps its NPL below $8 \%$ by Bank Indonesia regulations, so that it can produce good profitability in line with investor expectations.

\section{References}

[1] Babatunde, A., \& Olaitan, A. (2013). The Performance of Conventional and Islamic Banks in the United Kingdom: A Comparative Analysis. Journal of Research in Economics and International Finance (JREIF), 2(2), 29-38. Retrieved from https://www.interesjournals.org/articles/the-performance-of-conventional-and-islamicbanks-in-the-united-kingdom-a-comparative-analysis.pdf

[2] Darsono dan Ashari (2004) Pedoman Praktis Memahami Laporan Keuangan. Yogyakarta: Penerbit Andi.

[3] Fayed, M. E. (2013). Comparative Performance Study of Conventional and Islamic Banking in Egypt. Journal of Applied Finance \& Banking, 3(2), 1-14. Retrieved from http://www.scienpress.com/Upload/JAFB\%2FVol 3_2_1.pdf

[4] Kozarevic, E., Nuhanovic, S., \& Nurikic, M. B. (2013). Comparative Analysis of Risk Management in Conventional and Islamic Banks: The Case of Bosnia and Herzegovina. International Business Research. https://doi.org/10.5539/ibr.v6n5p180

[5] Kasmir (2014) Bank Dan Lembaga Keuangan lainnya. Jakarta: Raja Grafindo Persada.

[6] Massah, S. El, \& Al-Sayed, O. (2015). Banking Sector Performance: Islamic and Conventional Banks in the UAE. International Journal of Information Technology and Business Management, 36(1), 69-81. https://doi.org/DF508

[7] Rindawati, Ema (2007) Analisa Perbandingan Kinerja Perbankan Syariah dengan Perbankan Konvensional. UII, Yogyakarta.

[8] Samad, A. (2004). Performance of interest-free Islamic banks vis-a-vis interest-based conventional banks of Bahrain. IIUM Journal of Economics \& Management, 12(2), 115. Retrieved from https://journals.iium.edu.my/enmjournal/index.php/enmj/article/view/99/82

[9] Sofyan, M. (2016). Pengaruh Suku Bunga Kredit Modal Kerja, Capital Adequacy Ratio dan Loan to Deposit Ratio Terhadap Kredit Modal Kerja Bank Perkreditan Rakyat. Ekonomika, 9(2), 131-137. Retrieved from https://www.kopertis7.go.id/jurnal_lengkapEkonomika-9-2-01 122016

[10] Usman, A., \& Khan, M. K. (2012). Evaluating the Financial Performance of Islamic and Conventional Banks of Pakistan: A Comparative Analysis Abid Usman Sarhad University of Science \& Information Technology. International Journal of Business and Social Science, 3(7), 253-257. Retrieved from http://ijbssnet.com/journals/Vol_3_No_7_April_2012/27.pdf

[11] Yudistra, D. (2003). Efficiency in Islamic Banking: An Empirical Analysis of 18 Banks. Islamic Financial Architecture - Risk Management and Financial Stability, 16(4-5), 259-277. https://doi.org/10.1080/09720529.2013.821361 